\title{
Glucocorticoids and endothelial cell barrier function
}

\author{
Ellaine Salvador • Sergey Shityakov • Carola Förster
}

Received: 27 September 2013 / Accepted: 5 November 2013 /Published online: 19 December 2013

(C) The Author(s) 2013. This article is published with open access at Springerlink.com

\begin{abstract}
Glucocorticoids (GCs) are steroid hormones that have inflammatory and immunosuppressive effects on a wide variety of cells. They are used as therapy for inflammatory disease and as a common agent against edema. The blood brain barrier (BBB), comprising microvascular endothelial cells, serves as a permeability screen between the blood and the brain. As such, it maintains homeostasis of the central nervous system (CNS). In many CNS disorders, BBB integrity is compromised. GC treatment has been demonstrated to improve the tightness of the BBB. The responses and effects of GCs are mediated by the ubiquitous GC receptor (GR). Ligand-bound GR recognizes and binds to the GC response element located within the promoter region of target genes. Transactivation of certain target genes leads to improved barrier properties of endothelial cells. In this review, we deal with the role of GCs in endothelial cell barrier function. First, we describe the mechanisms of GC action at the molecular level. Next, we discuss the regulation of the BBB by GCs, with emphasis on genes targeted by GCs such as occludin, claudins and VE-cadherin. Finally, we present currently available GC therapeutic strategies and their limitations.
\end{abstract}

Keywords Glucocorticoids · Glucocorticoid receptor · Blood brain barrier $\cdot$ Endothelial cells

\section{Introduction}

Glucocorticoids (GCs) belong to a class of steroid hormones that bind to GC receptors (GRs), which, once activated as a complex, upregulate the expression of anti-inflammatory

E. Salvador $\cdot$ S. Shityakov $\cdot$ C. Förster $(\bowtie)$

Department of Anesthesia and Critical Care, Center for Operative

Medicine, University Hospital Würzburg, Würzburg, Germany

e-mail: Foerster_C@ukw.de proteins in the nucleus and repress the expression of proinflammatory proteins in the cytosol (Rhen and Cidlowski 2005). GCs are the first-choice therapy for inflammatory disease and a common anti-edematous agent. Administration of GCs is employed as a novel treatment strategy for several central nervous system (CNS) diseases such as brain tumors, brain edema and multiple sclerosis (MS).

The neurovascular unit of the CNS is made up of microvascular endothelial cells that seal the paracellular spaces between the blood and brain and, thus, are often referred to as the blood brain barrier (BBB), together with circulating blood components, pericytes, astrocytes and neurons (Neuwelt et al. 2008). In many disorders of the CNS, the integrity of the BBB is compromised. Since GCs are found to improve barrier properties, they are often used for the therapy of CNS disorders that involve the BBB. GC treatment has demonstrated a tightening of the $\mathrm{BBB}$ in the murine microvascular brain endothelial cells, cEND (Förster et al. 2005, 2006).

\section{Mechanisms of GC action at the molecular level}

GCs act on a wide variety of cell types leading to many different physiological and pathological responses and systemic effects. These responses and effects are mostly attributable to the ubiquitous nature of the GR. The action of GCs begins when the GC crosses the cell membrane and binds to a GR (Fig. 1). GRs are located in the cytoplasm and belong to the thyroid/retinoic acid receptor superfamily, which is composed of ligand-dependent transcription factors (Evans 1988; Tsai and O'Malley 1995). Within the cytoplasm, GRs are maintained in an inactive state by being bound to heat shock proteins (hsps) to prevent them from moving into the nucleus (Wikstrom et al. 1986; Picard et al. 1988; Dao-Phan et al. 1997). Once the GC binds to a GR, the hsps dissociate and the 
Fig. 1 Mechanisms of glucocorticoid $(G C)$ action. GC crosses the cell membrane and binds to the glucocorticoid receptor $(G R)$ in the cytoplasm. GRs are kept in an inactive state and prevented from moving into the nucleus by heat shock proteins $(H S P)$. Upon binding of a $\mathrm{GC}$ to a GR, the HSP dissociates and the GC-GR complex moves to the nucleus via a nuclear pore $(N P)$. The complex then binds to GCresponsive elements $(G R E)$ in the 5 ' promoter region of DNA.

Transcription is then activated.

However, if the region contains a negative GRE, transcription is repressed

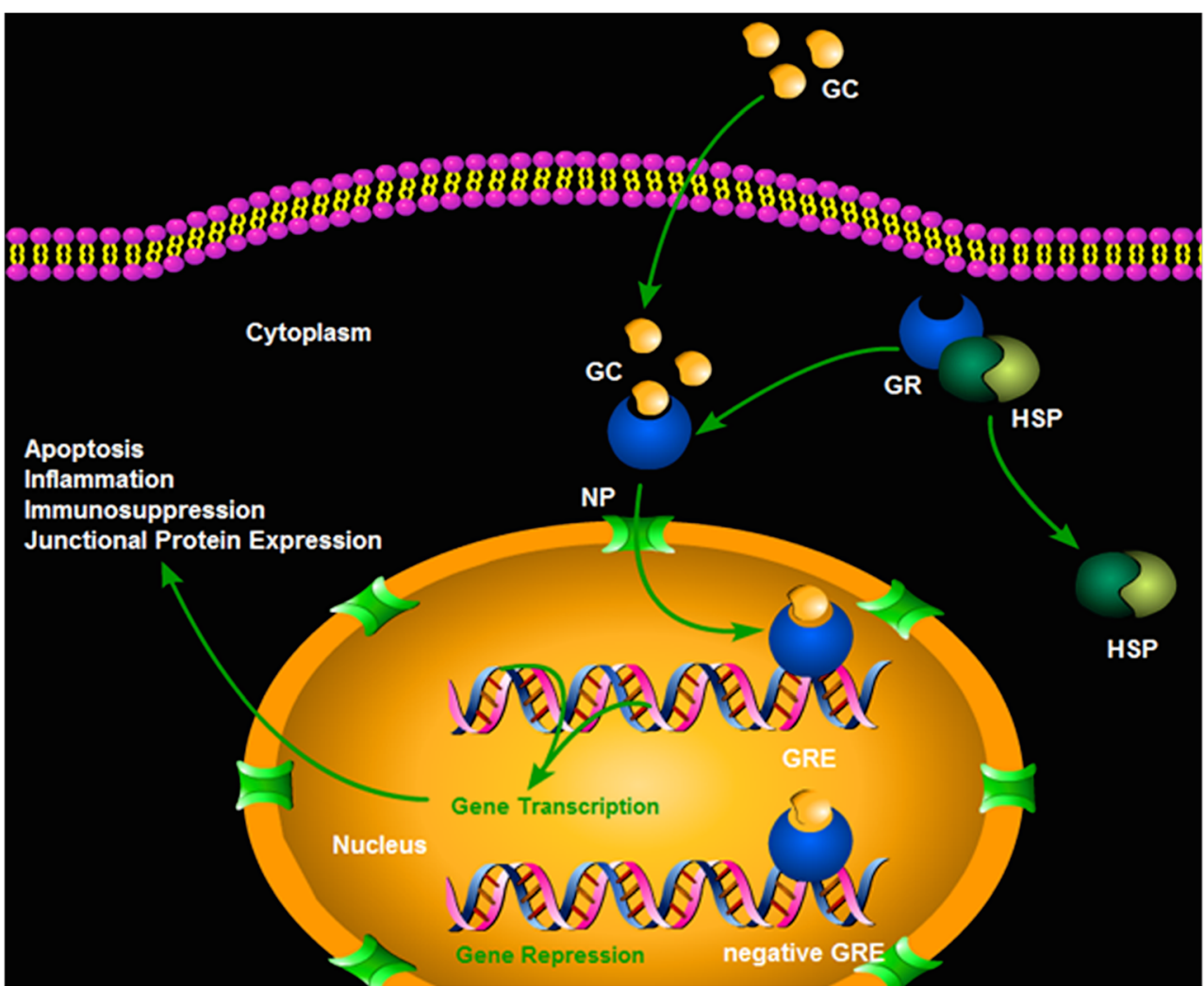

GC-GR complex then translocates into the nucleus in which it dimerizes with a second GC-GR complex (Dittmar et al. 1997; Hawle et al. 2006).

The zinc-finger domains of the GR can bind to specific DNA sequences, i.e., GC-responsive elements (GREs), in the 5' promoter region. The GR can then activate transcription in a process termed GR transactivation (Beato 1989; Schaaf and Cidlowski 2003; Harke et al. 2008). However, if the region contains a negative GRE, transcription is repressed (Sakai et al. 1988; Drouin et al. 1989; Nakai et al. 1991; Subramaniam et al. 1998).

The inflammatory and immunosuppressive effects of GCs rely on several molecular mechanisms that include (1) direct effects on gene expression by the binding of GRs to GREs; (2) indirect effects on gene expression by the interaction of GRs with other transcription factors; (3) GR-mediated effects on second messenger cascades, i.e., the P13K-Akt-eNOS pathway (Rhen and Cidlowski 2005).

\section{Glucocorticoid receptor}

GRs mediate the biological effects of GCs (Beato 1989). They are a type II steroid receptor and transcription factor and alter the expression of target genes involved in multiple cellular processes such as immune function, inflammation and cell death (Schaaf and Cidlowski 2003). As a type II receptor, GR is expressed in almost all tissues and cells. It has a binding affinity for cortisol of approximately $30 \mathrm{nM}$, which is within the physiological range of serum cortisol values (Umland et al. 2002). GR is expressed in two isoforms, namely, GR $\alpha$ and GR $\beta$, which share identical N-termini and are distinguished only by their unique $\mathrm{C}$-terminal ligand-binding domain (LewisTuffin and Cidlowski 2006). GR $\alpha$ binds cortisol, DNA and other transcription factors, thereby modifying the transcriptional activity of target genes (Lu and Cidlowski 2004). On the other hand, GR $\beta$ does not bind any ligands and fails to activate transcription, although it forms homodimers that bind DNA. Relative levels of these two GR isoforms in a cell influence the sensitivity of the cell to GC. Higher levels of GR $\beta$ lead to GC resistance (Pujols et al. 2001).

\section{Blood brain barrier}

The BBB is a diffusion barrier essential for the normal functioning of the CNS (Ballabh et al. 2004). It is composed of highly specialized endothelial cells, which, together with circulating blood components, pericytes, astrocytes, microglia, neurons and basement membrane form a neurovascular unit (Neuwelt et al. 2008). The capillary endothelial cells that make up the BBB are formed by tight junctions (TJs) that seal paracellular spaces between the endothelial cells thereby restricting paracellular permeability (Wolburg and Lippoldt 2002; Förster 2008). The integral membrane proteins claudin, 
occludin and junction adhesion molecules make up the TJs, alongside a number of cytoplasmic accessory proteins including zonula occludens (ZO)-1, ZO-2, ZO-3 and cingulin (Ballabh et al. 2004). Junctional protein disintegration plays a major role in BBB breakdown during MS, meningitis, or brain neoplasm (Förster et al. 2008).

\section{Regulation of BBB by GCs}

Many factors regulate the BBB. Changes in the expression of junctional proteins in the endothelial cells through metabolic or cellular mediators play a role in this regulation leading to dynamic changes in BBB properties (Madra et al. 1986; Madara 1988; Schneeberger and Lynch 1992; Citi 1993; Leach et al. 2000; Schweingruber et al. 2011). However, GCs are also important regulators of BBB properties together with other factors such as growth factors or calcium. Treatment of tumor-induced brain edema by GC reduces microvessel permeability. Several studies have demonstrated the molecular mechanisms behind this. For instance, treatment of epithelial cells with dexamethasone, a synthetic GC, influences the differentiation of TJ proteins (Buse et al. 1995). It increases transendothelial electrical resistance (TER) and ZO1 expression (Singer et al. 1994). In addition, dexamethasone has also been found to influence $\mathrm{TJ}$ expression leading to a reduction of permeability in rat (Romero et al. 2003; Calabria et al. 2006), murine (Förster et al. 2005; Weidenfeller et al. 2005), porcine (Hoheisel et al. 1998; Lohmann et al. 2002) and human (Weksler et al. 2005; Förster 2008) endothelial cells. In the advent of a neuroinflammatory response, cell adhesion molecules such as intercellular adhesion molecule-1 (ICAM-1) and vascular cell adhesion molecule-1 (VCAM-1) become upregulated on endothelial cells facilitating lymphocyte extravasation across the BBB (Engelhardt 2006). GCs inhibit BBB disruption thereby reducing leukocyte infiltration into the CNS (Paul and Bolton 1995).

\section{Genes of vascular endothelium targeted by GCs}

\section{Occludin}

The TJ protein occludin was the first integral protein to be identified, initially in the chicken (Furuse et al. 1993) and then in mammals (Anko-Akatsuka et al. 1996). It is composed of four transmembrane domains, two extracellular loops of similar size, three cytoplasmic domains, a short cytoplasmic Nterminus and a long C-terminus (Gonzalez-Mariscal et al. 2003). Although occludin localizes at the TJs, it cannot form TJ strands by itself (Furuse et al. 1996). In addition, the formation of an effective diffusion barrier and epithelial cell polarization are not prevented by the disruption of both occludin alleles in embryonic stem cells (Saitou et al. 1998). Moreover, occludin knock-out mice display well-developed TJs (Saitou et al. 2000).

Nonetheless, several lines of evidence show that occludin plays an important role at TJs. It contributes to the electrical barrier function of $\mathrm{TJ}$ s and possibly to the formation of aqueous pores within TJ strands (McCarthy et al. 1996). Moreover, the N-terminal half of occludin has demonstrated its important role for TJ assembly and barrier function maintenance (Bamforth et al. 1999). Overexpression of occludin increases TER in mammalian epithelial cells (Balda et al. 1996). Originally hydrocortisone (HC) was reported to reinforce blood-brain properties in a serum-free cell culture system of cultured porcine cerebral capillary endothelial cells (Hoheisel et al. 1998). Next, GCs were shown to induce a more differentiated BBB phenotype through the modification of TJ structure in cultured rat brain endothelial cells (Romero et al. 2003). Then, the tightening effects of GC treatment was demonstrated in the murine cerebrovascular endothelial cell line cEND (Förster et al. 2005, 2006) and in human hDMEC/ D3 cells (Förster 2008). Study of GC effects on the improvement of BBB properties in a murine in vitro system was, for the first time, able to identify occludin as a direct target for GC (Förster et al. 2005). GCs were shown to induce occludin expression (Fig. 2); this was dependent on the GR. A GC response element (GRE) was identified as a GR-binding site within the occludin promoter. This indicated that transactivation of occludin occurred through the GRE (Harke et al. 2008). Moreover, GC treatment antagonized the effects of tumor necrosis factor- $\alpha$ (TNF- $\alpha)$ on occludin expression in endothelial cell lines (Silwedel and Förster 2006).

\section{Claudins}

Despite disruption of both alleles of the occludin gene in embryonic stem (ES) cells, well-developed TJs were found between adjacent epithelial cells. This led to the conclusion that occludin was not necessarily required for TJ formation itself and indicated that other unidentified TJ integral membrane protein(s) could form strand structures without occludin (Saitou et al. 1998). Concomitantly, peptide sequencing led to the discovery of two putative TJ integral proteins that were

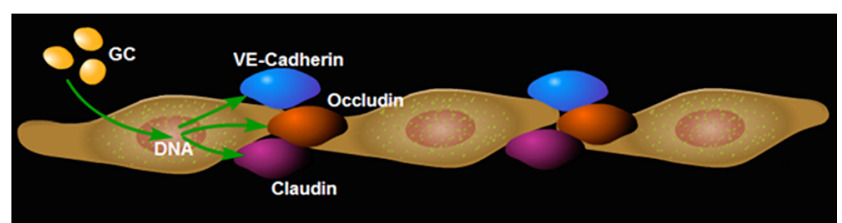

Fig. 2 Genes of the microvascular endothelium are targeted by glucocorticoids $(G C)$. GC treatment induces the expression of tight junction proteins occludin and claudin- 5 and the adherens junction protein vascular endothelium cadherin (VE-Cadherin) 
subsequently named claudin 1 and 2 (Furuse et al. 1998). So far, 24 members of the claudin family have been identified (Tsukita et al. 2001). These proteins show sequence similarity to each other and also bear four putative transmembrane domains but do not show any sequence similarity to occludin (Furuse et al. 1998).

Endothelial cells of the BBB express claudin-1, $-3,-5$ and -12 (Wolburg and Lippoldt 2002; Krause et al. 2008). Claudin-5 plays an important role in the maintenance of BBB function. Mice that are claudin-5-deficient are born alive but die within a day after birth with no morphological abnormalities. This can be attributed to the integrity of the BBB of these mice being severely decreased, since it is selectively permeable to molecules with a size of $<800 \mathrm{Da}$ (Nitta et al. 2003).

The murine claudin- 5 promoter has been cloned and characterized (Burek and Förster 2009). Putative GREs in the promoter sequence have been identified. An increase in claudin- 5 promoter activity and mRNA expression occurs after dexamethasone treatment. In addition, increased claudin-5 mRNA and protein expression resulting in higher TER of the endothelial cells has been observed after GC treatment (Fig. 2; Förster et al. 2006; Felinski et al. 2008; Förster 2008; Sadowska et al. 2010). Claudin-5 is also regulated by estrogens on promoter, mRNA and protein levels (Burek et al. 2010).

\section{Vascular endothelium cadherin}

Together with TJs, adherens junctions (AJs) maintain the restrictiveness of the barrier in endothelial cells (Fig. 2). The most important AJ protein is vascular endothelial cadherin (VE-cadherin), which is exclusively expressed in vessels in which it regulates $\mathrm{Ca}^{2+}$-mediated adhesion (Dejana et al. 1999; Dejana 2004; Gumbiner 2005; Gavard 2009). Deletion of VE-cadherin in mice produces massive vascular effects leading to early embryonic death. On the other hand, loss of its function provokes a hyperpermeability in adults (Carmeliet et al. 1999; Crosby et al. 2005).

Treatment of endothelial cells with dexamethasone increases VE-cadherin protein levels. Transcriptional activation of the VE-cadherin promoter by dexamethasone, however, does not point to direct GC-mediated VE-cadherin gene induction (Blecharz et al. 2008). Although TJs and AJs are formed by different molecules, they are functionally and structurally linked. VE-cadherin at AJs upregulates the gene encoding claudin- 5 via the release of the inhibitory activity of the forkhead box factor FoxO1 and the Tcf-4-beta-catenin transcriptional repressor complex (Taddei et al. 2008).

\section{GC therapeutic strategies and their limitations}

The BBB is compromised in many CNS disorders. To function normally, the CNS needs to maintain its microenvironment; this is performed by the $\mathrm{BBB}$ via its regulation of molecule transport between the blood and the brain. Since TJ and AJ proteins contribute to endothelial cell barrier restrictiveness, the effects of GCs toward upregulation in the expression of these proteins leading to a tightening of the barrier are used to advantage for therapeutic purposes against many diseases of the CNS including MS, human immunodeficiency (HIV)-1-associated dementia, CNS vasculitides, stroke, Alzheimer's disease and cerebral malaria (Fig. 3).

\section{Multiple sclerosis}

MS, a neuroinflammatory disorder characterized by infiltrating autoreactive T-cells in the CNS, is the most prevalent chronic autoimmune disease in the western world (Noseworthy et al. 2000; Sospedra and Martin 2005). Most patients suffer from a relapsing-remitting form of the disease whose exacerbations are initiated by BBB breakdown and subsequent tissue damage. Because of the infiltration of activated immune effector cells into the brain, an inflammatory cascade involving leukocytes and humoral components arises (Steinman 2001; Engelhardt 2006). Even though GC treatment has little effect on the long-term prognosis of MS, high dosage GC therapy is an approved first line treatment for MS relapses (Milligan et al. 1987; Reichhardt 2004).

For more than 70 years, experimental autoimmune encephalomyelitis (EAE) has served as a model for MS (Gold et al. 2006). In using this model, together with studies of MS patient, multiple beneficial effects of GC treatment have been established. GCs have anti-inflammatory and immunosuppressive activities and can induce apoptosis. Their induction of apoptosis in T-cells leads to the activation of caspases,

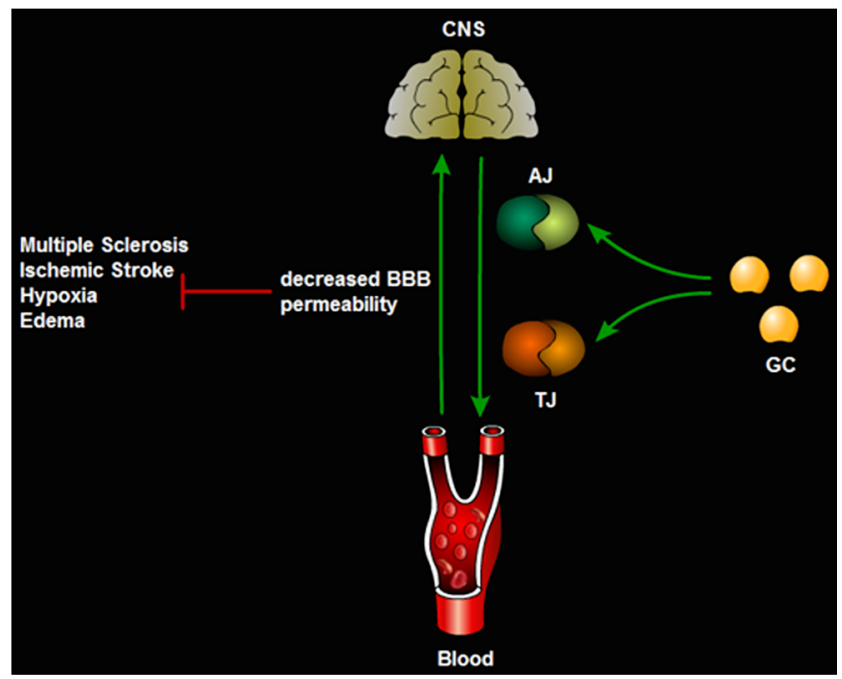

Fig. 3 Most diseases and disorders of the central nervous system (CNS) involve the disruption of the blood brain barrier $(B B B)$, decreasing its permeability. Administration of glucocorticoids $(G C)$ induces the expression of adherens junctions $(A J)$ and tight junctions $(T J)$ leading to increased barrier tightness 
release of cathepsin $\mathrm{B}$ from lysosomes and increased $\mathrm{H}_{2} \mathrm{O}_{2}$ levels (Screpanti et al. 1989; Gold et al. 2006). GCs inhibit the disruption of the BBB and hence reduce leukocyte infiltration into the CNS (Paul and Bolton 1995). Direct effects of GCs on the BBB have been demonstrated in vitro (Tischner and Reichardt 2007). For instance, in cultured brain endothelial cells, dexamethasone induces pore reduction and F-actin concentration on the cell periphery and increases ZO-1 and occludin expression (Romero et al. 2003; Förster et al. 2005, 2006). In addition, the administration of dexamethasone and $\mathrm{HC}$ preserves the functional integrity of TJs and AJs under pro-inflammatory conditions by maintaining the levels of $\mathrm{TJ}$ components such as occludin, claudin-1, claudin-12, ZO-1 and VE-cadherin. However, dexamethasone effects on claudin-5 are negligible (Förster et al. 2007; Blecharz et al. 2008).

ICAM-1 and VCAM-1 are expressed by endothelial cells of the BBB in response to pro-inflammatory cytokines such as interferon- $\gamma$ and TNF $\alpha$. Treatment with GCs reduces the expression of these adhesion molecules (Gelati et al. 2000; Sloka and Stefanelli 2005). Accordingly, integrins on encephalitogenic T-cells interact with these adhesion molecules, which are required for the extravasation of additional effector T-cells into the CNS (Engelhardt 2006). Production of interleukin-8 by monocytes, which also contributes to BBB disruption through leukocyte recruitment to the CNS, is also decreased in MS patients following GC treatment (MirowskaGuzel et al. 2006).

The opening of the BBB as promoted by cytokines has been shown to occur because of TJ protein degradation and decreased synthesis. This results in compromised junctional integrity (Harkness et al. 2000; Chang and Werb 2001; Silwedel and Förster 2006; Yang et al. 2007). TJ degradation in neuroinflammatory conditions such as MS results from the effects of matrix metalloproteinases (MMPs) in BBB disruption. MMP-9 (gelatinase B) is increased in cerebrospinal fluid levels in MS patients. An important regulator of MMP activity is via binding to a family of homologous proteins referred to as tissue inhibitors of MMPs (TIMPs; Brew et al. 2000). All four known TIMPS have been demonstrated in the BBB endothelium (Hartmann et al. 2009). In MS patients, TIMP levels are reduced in comparison with controls. This suggests an imbalance in MMP-9/TIMP ratios (Avolio et al. 2005). GC treatment reduces levels of MMP-9, based on the GCmediated activation of the TIMP-1 gene and has been shown to lead to an upregulation of TIMP-1 in the murine cerebral vascular endothelial cell line, cEND (Förster et al. 2007). In contrast, $\mathrm{HC}$ has been revealed selectively to upregulate TIMP-3, whereas TIMP-1, TIMP-2 and TIMP-4 are downregulated at the mRNA-level in endothelial cells of cerebral capillaries in porcine brain. This effect can be completely reversed by the GR inhibitor mifepristone. The application of $\mathrm{HC}$ leads to a strong enrichment of TIMP-3 in the endothelial cell membrane (Hartmann et al. 2009). Moreover, the downregulation of claudin- 5 and occludin protein and mRNA levels occurs together with MMP-9 expression upregulation after incubation of the murine microvascular endothelial cells, cEND, with serum from MS patients (Blecharz et al. 2010).

Ischemic stroke

GCs are known to stabilize the BBB in many inflammatory CNS disorders and even to decrease edema formation. However, in some other cases of CNS disease, it tends to aggravate the condition rather than diminish the negative effects. For instance, when GC treatment is applied to acute ischemic stroke, it is ineffective or even harmful (Saul et al. 1981; Norris and Hachinski 1986; De Reuck et al. 1988; Kumar et al. 1989; Norris 2004; Poungvarin 2004; Roberts et al. 2004). This is attributed to GC insensitivity at the hypoxic BBB. In the cultured murine brain microvascular endothelial cells, cEND, $\mathrm{O}_{2}$ /glucose deprivation reduces TJ protein expression and TER. Treatment with dexamethasone fails to reverse these effects during hypoxia. Apparently, proteasomedependent degradation of the GR impairs GR transactivation, in turn preventing physiological GC activity. Inhibition of the proteasome with Bortezomib, however, fully restores the $\mathrm{BBB}$ stabilizing properties of $\mathrm{GC}$ during $\mathrm{O}_{2}$ /glucose deprivation (Kleinschnitz et al. 2011).

Effects of ubiquitination on GC response during hypoxia

Post-translational modifications of the GR include phosphorylation under various conditions by cyclin-dependent kinases and mitogen-activated protein kinases (MAPKs), sumoylation and ubiquitination (Tischner and Reichardt 2007). Ubiquitination determines protein longevity in cells and plays major roles in signaling (Ernst and Sidhu 2013) being a form of post-translational modification that targets a protein for rapid degradation by the proteasome (Meller 2009). Excessive proteosomal GR degradation in response to long-term GC exposure has been shown to lead to GC insensitivity in the vascular endothelium (Förster et al. 2006). An endothelial GR protein has been identified as a potential proteasome substrate after hypoxia (Kleinschnitz et al. 2011).

$\mathrm{GC}$ responses are dependent on the post-translational modification and degradation of GR to which GC binds to form a complex and begin its activity. The ubiquitin-proteosome system plays a major part in this modification and degradation. Degradation of the proteasome by nuclear receptors is a physiological process necessary to terminate transcriptional activity after ligand binding. It can, however, also restrict transcriptional signaling by steroids under certain pathophysiological conditions thereby compromising steroid function (Meller 2009). In an in vitro $\mathrm{BBB}$ model subjected to $\mathrm{O}_{2}$ /glucose deprivation, degradation of the GR in a proteasome-dependent manner 
leading to impaired GC sensitivity has been observed. When the proteasome is inhibited, the responsivity of the BBB to GC during hypoxia is restored. When proteosomal inhibition is combined with GC treatment, edema formation is attenuated, as are neurological deficits after transient middle cerebral artery occlusion (tMCAO) in mice, which is an established in vivo model of hypoxic BBB damage (Kleinschnitz et al. 2011).

In addition, studies have shown that cell-death-mediating proteins are rapidly degraded by the ubiquitin-proteosome system. For instance, some pro-apoptotic proteins such as Bim and Puma have been identified as direct GR targets (Erlacher et al. 2005; Wang et al. 2006). Therefore, a better understanding of the mechanisms by which this occurs might prove to be useful for therapy during ischemia and other brain injuries.

Action of GC-based combination therapy with proteosomal inhibitors against edema

Although GCs diminish edema formation in neuroinflammatory diseases such as acute MS lesions and in certain brain tumors, they are ineffective or even harmful in brain disorders such as acute ischemic stroke or traumatic brain injury (TBI; Kumar et al. 1989). Stroke and other forms of ischemic brain injury result in excessive edema formation in the brain leading to morbidity and mortality (Kahle et al. 2009). Therefore, the finding that GCs can diminish edema in some neuroinflammatory diseases but not in ischemia or TBI is unfortunate.

Degradation of GR occurs during $\mathrm{O}_{2} /$ glucose deprivation in cEND cells and in the tMCAO model of stroke (Kleinschnitz et al. 2011). However, the use of pharmacological proteasome inhibitors is able to prevent it. GR transactivation by GC binding has been found to be maintained through the overexpression of a GR mutant resistant to proteasomal degradation (GR-K426A mutant; Wallace and Cidlowski 2001). These findings have led to the development of a combined treatment strategy by using GCs combined with inhibitors of the proteasome. This novel therapy effectively and significantly reduces edema formation. Furthermore, it significantly ameliorates neurological performance in mouse models of stroke and TBI (Kleinschnitz et al. 2011).

\section{Concluding remarks}

The ability of GCs to improve barrier properties and induce the expression of TJ proteins occludin and claudin- 5 and AJ protein VE-cadherin demonstrates their positive effects toward the BBB. Even though high dosage administration of GCs has been found to be ineffective or even harmful in brain disorders such stroke or TBI, novel strategies such as combination therapy of GCs and proteasome inhibitors have proven effective in the prevention of BBB disruption, edema formation and neuronal damage upon brain injury both in vivo and in vitro.
Therefore, further studies concerning the GR-mediated regulation of BBB permeability are needed for the development of more and better therapeutic strategies with GCs.

Currently, the establishment of an in vitro human stroke model based on human brain capillary endothelial cells in our working group together with cooperating partners is underway. The model is in the process of being tested, verified and strengthened for use in various experimental procedures. Once this model is established, it should prove highly beneficial in medical and biological research.

Open Access This article is distributed under the terms of the Creative Commons Attribution License, which permits any use, distribution and reproduction in any medium, provided the original author(s) and the source are credited.

\section{References}

Anko-Akatsuka Y, Saitou M, Hirase T, Kishi M, Sakakibara A, Itoh M, Yonemura S, Furuse M, Tsukita S (1996) Interspecies diversity of the occludin sequence: cDNA cloning of human, mouse, dog, and rat-kangaroo homologues. J Cell Biol 133:43-47

Avolio C, Filippi M, Tortorella C, Rocca MA, Ruggieri M, Agosta F, Tomassini V, Pozzili C, Stecchi S, Giaquinto P, Livrea P, Trojano M (2005) Serum MMP-9/TIMP-1 and MMP-2/TIMP-2 ratios in multiple sclerosis: relationships with different magnetic resonance imaging measures of disease activity during IFN-beta-1a treatment. Mult Scler 11:441-446

Balda MS, Whitney J, Flores C, Gonzalez S, Cereijido M, Malter K (1996) Functional dissociation of paracellular permeability and transepithelial electrical resistance and disruption of the apicalbasolateral intramembrane diffusion barrier by expression of a mutant tight junction membrane protein. J Cell Biol 134:10311049

Ballabh P, Braun A, Nedergaard M (2004) The blood brain barrier: an overview. Structure, regulation, and clinical implications. Neurobiol Dis 16:1-13

Bamforth SD, Kniesel U, Wolburg H, Engelhardt B, Risau W (1999) A dominant mutant of occludin disrupts tight junction structure and function. J Cell Sci 112:1879-1888

Beato M (1989) Gene regulation by steroid hormones. Cell 56:335-344

Blecharz KG, Drenckhahn D, Förster CY (2008) Glucocorticoids increase VE-cadherin expression and cause cytoskeletal rearrangements in murine brain endothelial cEND cells. J Cereb Blood Flow Metab 28:1139-1149

Blecharz KG, Haghikia A, Stasiolek M, Kruse N, Drenckhahn D, Gold R, Roewer N, Chan A, Förster CY (2010) Glucocorticoid effects on endothelial barrier function in the murine barin endothelial cell line cEND incubated with sera from patients with multiple sclerosis. Mult Scler 16:293-302

Brew K, Dinakarpandian D, Nagase H (2000) Tissue inhibitors of metalloproteinases: evolution, structure and function. Biochem Biophys Acta 1477:267-283

Burek M, Förster CY (2009) Cloning and characterization of the murine claudin-5 promoter. Mol Cell Endocrinol 298:19-24

Burek M, Arias-Loza PA, Roewer N, Förster C (2010) Claudin-5 as a novel estrogen target in vascular endothelium. Arterioscler Thromb Vasc Biol 30:298-304

Buse P, Woo PL, Alexander DB, Reza A, Firestone GL (1995) Glucocorticoid-induced functional polarity of growth factor 
responsiveness regulates tight junction dynamics in transformed mammary epithelial tumor cells. J Biol Chem 270:28223-28227

Calabria AR, Weidenfeller C, Jones AR, de Vries HE, Shusta EV (2006) Puromycin-purified rat brain microvascular endothelial cell cultures exhibit improved barrier properties in response to glucocorticoid induction. J Neurochem 97:922-933

Carmeliet P, Lampugnani M, Moons L, Breviario F, Compernolle V, Bono F, Balconi G, Spagnuolo R, Oosthuyse B, Dewerchin M, Zanetti A, Angellilo A, Mattot V, Nuyens D, Lutgens E, Clotman F, de Ruiter MC, Gittenberger-de Groot A, Poelmann R, Lupu F, Herbert JM, Collen D, Dejana E (1999) Targeted deficiency or cytosolic truncation of the VE-cadherin gene in mice impairs VEGF-mediated endothelial survival and angiogenesis. Cell 98:147-157

Chang C, Werb Z (2001) The many faces of metalloproteases: cell growth, invasion, angiogenesis and metastasis. Trends Cell Biol 11:S37-S43

Citi S (1993) The molecular organization of tight junctions. J Cell Biol 121:485-489

Crosby CV, Fleming P, Argraves WS, Corada M, Zanetta L, Dejana E, Drake CJ (2005) VE-cadherin is not required for the formation of nascent blood vessels but acts to prevent their disassembly. Blood 105:2771-2776

Dao-Phan HP, Formstecher P, Lefebvre P (1997) Disruption of the glucocorticoid receptor assembly with heat shock protein 90 by a peptidic antiglucocorticoid. Mol Endocrinol 11:962-972

De Reuck J, Vandekerckhove T, Bosma G, De Meulemeester K, Van Landegem W, De Waele J, Tack E, De Koninck J (1988) Steroid treatment in acute ischaemic stroke. A comparative retrospective study of 556 cases. Eur Neurol 28:70-72

Dejana E (2004) Endothelial cell-cell junctions: happy together. Nat Rev Mol Cell Biol 5:261-270

Dejana E, Bazzoni G, Lampugnani MG (1999) Vascular endothelial (VE)-cadherin: only an intercellular glue? Exp Cell Res 252:13-19

Dittmar KD, Demady D, Stancato LF, Krishna P, Pratt WB (1997) Folding of the glucocorticoid receptor by the heat shock protein (hsp) 90-based chaperone machinery. The role of p23 is to stabilize receptor.hsp90 heterocomplexes formed by hsp90.p60.hsp70. J Biol Chem 272:21213-21220

Drouin J, Lu Y, Nemer M (1989) Glucocorticoid repression of proopiomelanocortin gene transcription. J Steroid Biochem 34:63-69

Engelhardt B (2006) Molecular mechanisms involved in T cell migration across the blood-brain barrier. J Neural Transm 113:477-485

Erlacher M, Michalak EM, Kelly PN, Labi V, Niederegger H, Coultas L, Adams JM, Strasser A, Villunger A (2005) BH3-only proteins Puma and Bim are rate-limiting for gamma-radiation- and glucocorticoidinduced apoptosis of lymphoid cells in vivo. Blood 106:4131-4138

Ernst A, Sidhu S (2013) Engineering ubiquitin to modulate the ubiquitin proteosome system. Cell Cycle 12:1651-1652

Evans R (1988) The steroid and thyroid hormone superfamily. Science 240:889-895

Felinski EA, Cox A, Phillips BE, Antonetti DA (2008) Glucocorticoids induce transactivation of tight junction genes occludin and claudin-5 in retinal endothelial cells via a novel cis-element. Exp Eye Res 86: $867-878$

Förster C (2008) Tight junctions and the modulation of barrier function ion disease. Histochem Cell Biol 130:55-70

Förster C, Silwedel C, Golenhofen N, Burek M, Kietz S, Mankertz J, Drenckhahn D (2005) Occludin as direct target for glucocorticoidinduced improvement of blood-brain barrier properties in a murine in vitro system. J Physiol (Lond) 565:475-486

Förster C, Waschke J, Burek M, Leeres J, Drenckhahn D (2006) Glucocorticoid effects on microvascular endothelial barrier permeability are brain specific. J Physiol (Lond) 573:413-425

Förster C, Kietz S, Kahles T, Drenckhahn D (2007) Dexamethasone induces the expression of metalloproteinase inhibitor TIMP-1 in the murine cerebral vascular endothelial cell line cEND. J Physiol (Lond) 580:937-949
Förster C, Burek M, Romero IA, Weksler B, Couraud PO, Drenckhahn D (2008) Differential effects of hydrocortisone and TNF alpha on tight junction proteins in an in vitro model of the human blood brain barrier. J Physiol (Lond) 586:1937-1949

Furuse M, Hirase T, Itoh M, Nagafuchi A, Yonemura S, Tsukita S (1993) Occludin: a novel integral membrane protein localizing at tight junctions. J Cell Biol 123:1777-1788

Furuse M, Fujimoto K, Sato N, Hirase T, Tsukita S (1996) Overexpression of occludin, a tight-junction associated integral membrane protein, induces the formation of intracellular multi-lamellar bodies bearing tight junction-like structures. J Cell Sci 109:429-435

Furuse M, Fujita K, Hiiragi T, Fujimoto K, Tsukita S (1998) Claudin-1 and -2 : novel integral membrane proteins localizing at tight junctions with no sequence similarity to occludin. J Cell Biol 141:1539-1550

Gavard J (2009) Breaking the VE-cadherin bonds. FEBS Lett 583:1-6

Gelati M, Corsini E, Dufour A, Massa G, Giombini S, Solero CL, Salmaggi A (2000) High-dose methylprednisolone reduces cytokine-induced adhesion molecules on human brain endothelium. Can J Neurol Sci 27:241-244

Gold R, Linington C, Lassmann H (2006) Understanding pathogenesis and therapy of multiple sclerosis via animal models: 70 years of merits and culprits in experimental autoimmune encephalomyelitis research. Brain 129:1953-1971

Gonzalez-Mariscal L, Betanzos A, Nava P, Jamarillo BE (2003) Tight junction proteins. Prog Biophys Mol Biol 81:1-44

Gumbiner BM (2005) Regulation of cadherin-mediated adhesion in morphogenesis. Nat Rev Mol Cell Biol 6:622-634

Harke N, Leers J, Kietz S, Drenckhahn D, Förster C (2008) Identification of a distal glucocorticoid responsive element in the occludin gene coding region. Mol Cell Endocrinol 295:39-47

Harkness KA, Adamson P, Sussman JD, Davies-Jones GA, Greenwood J, Woodroofe MN (2000) Dexamethasone regulation of matrix metalloproteinase expression in CNS vascular endothelium. Brain 123: 698-709

Hartmann C, El-Gindi J, Lohmann C, Lischper M, Zeni P, Galla HJ (2009) TIMP-3: a novel target for glucocorticoid signaling at the blood-brain barrier. Biochem Biophys Res Commun 390:182-186

Hawle P, Siepmann M, Harst A, Siderius M, Reusch HP, Obermann WM (2006) The middle domain of Hsp90 acts as a discriminator between different types of client protein. Mol Cell Biol 26:8385-8395

Hoheisel D, Nitz T, Franke H, Wegener J, Hakvoort A, Tilling T, Galla HJ (1998) Hydrocortisone reinforces the blood brain barrier properties in a serum-free cell-culture system. Biochem Biophys Res Commun 244:312-316

Kahle KT, Simard J, Staley KJ, Nahed BV, Jones PS, Sun D (2009) Molecular mechanisms of ischemic cerebral edema: role of electroneutral ion transport. Physiology (Bethesda) 24:257-265

Kleinschnitz C, Blecharz K, Kahles T, Schwarz T, Kraft P, Thum T, Stoll G, Förster C (2011) Glucocorticoid insensitivity at the hypoxic blood-brain-barrier can be reversed by inhibition of the proteasome. Stroke 42:1081-1089

Krause G, Winkler L, Mueller SL, Haseloff RF, Piontek J, Blasig IE (2008) Structure and function of claudins. Biochim Biophys Acta 1778:631-645

Kumar N, Jain S, Maheshwari MC (1989) Role of dexamethasone in the outcome from acute stroke. J Assoc Physicians India 37:315-317

Leach L, Lammiman M, Babawale MO, Hobson SA, Bromilou B, Lovat S, Simmonds MJ (2000) Molecular organization of tight and adherens junctions in the human placental vascular tree. Placenta 21:547-557

Lewis-Tuffin LJ, Cidlowski J (2006) The physiology of human glucocorticoid receptor beta (hGRbeta) and glucocorticoid resistance. Ann N Y Acad Sci 1069:1-9

Lohmann C, Hüwel S, Galla HJ (2002) Predicting blood brain barrier permeability of drugs: evaluation of different in vitro assays. J Drug Target 10:263-276 
Lu NZ, Cidlowski J (2004) The origin and functions of multiple human glucocorticoid receptor isoforms. Ann N Y Acad Sci 1024:102-123

Madara J (1988) Tight junction dynamics: is paracellular transport regulated? Cell 53:497-498

Madra JL, Barenberg D, Carlson S (1986) Effects of cytochalasin D on occludin junctions of intestinal absorptive cells: further evidence that the cytoskeleton may influence paracellular permeability and junctional charge selectivity. J Cell Biol 102:2125-2136

McCarthy KM, Skare I, Stankewich MC, Furuse M, Tsukita S, Rogers RA, Lynch RD, Schneeberger EE (1996) Occludin is a functional component of the tight junction. J Cell Sci 109:2287-2298

Meller R (2009) The role of the ubiqutitin proteosome system in ischemia and ischemic tolerance. Neuroscientist 15:243-260

Milligan NM, Newcombe R, Compston DA (1987) A double-blind controlled trial of high dose methylprednisolone in patients with multiple sclerosis. 1. Clinical effects. J Neurol Neurosurg Psychiatry 50:511-516

Mirowska-Guzel DM, Kurowska K, Skierski J, Koronkiewicz M, Wicha W, Kruszewska J, Czlonkowski A, Czlonkowska A (2006) High dose of intravenously given glucocorticosteroids decrease IL-8 production by monocytes in multiple sclerosis patients treated during relapse. J Neuroimmunol 176:134-140

Nakai Y, Usui T, Tsukada T, Takahashi H, Fukata J, Fukushima M, Senoo K, Imura H (1991) Molecular mechanisms of glucocorticoid inhibition of human pro-opiomelanocortin gene transcription. J Steroid Biochem Mol Biol 40:301-306

Neuwelt E, Abbott N, Abrey L, Banks WA, Blakley B, Davis T, Engelhardt B, Grammas P, Nedergaard M, Nutt J, Pardridge W, Rosenberg GA, Smith Q, Drewes LR (2008) Strategies to advance translational research into brain barriers. Lancet Neurol 7:84-96

Nitta T, Hata M, Gotoh S, Seo Y, Sasaki H, Hashimoto N, Furuse M, Tsukita S (2003) Size-selective loosening of the blood brain barrier in claudin-5 deficient mice. J Cell Biol 161:653-660

Norris J (2004) Steroids may have a role in stroke therapy. Stroke 35:228-229

Norris JW, Hachinski V (1986) High dose steroid treatment in cerebral infarction. BMJ 292:21-23

Noseworthy JH, Lucchinetti C, Rodriguez M, Weinshenker BG (2000) Multiple sclerosis. N Engl J Med 343:938-952

Paul C, Bolton C (1995) Inhibition of blood-brain barrier disruption in experimental allergic encephalomyelitis by short-term therapy with dexamethasone or cyclosporin A. Int J Immunopharmacol 17:497-503

Picard D, Salser S, Yamamoto KR (1988) A movable and regulable inactivation function within the steroid binding domain of the glucocorticoid receptor. Cell 54:1073-1080

Poungvarin N (2004) Steroids have no role in stroke therapy. Stroke 35: 229-230

Pujols L, Mullol J, Pérez M, Roca-Ferrer J, Juan M, Xaubet A, Cidlowski JA, Picado C (2001) Expression of human glucocorticoid receptor alpha and beta isoforms in human respiratory epithelial cells and their regulation by dexamethasone. Am J Respir Cell Mol Biol 24:49-57

Reichhardt H (2004) Immunomodulatory activities of glucocorticoids: insights from transgenesis and gene targeting. Curr Pharm Des 10: 2797-2805

Rhen T, Cidlowski J (2005) Antiinflammatory action of glucocorticoidsnew mechanisms for old drugs. N Engl J Med 353:1711-1723

Roberts I, Yates D, Sandercock P, Farrell B, Wasserberg J, Lomas G, Cottingham R, Svoboda P, Brayley N, Mazairac G, Laloe V, MunozSanchez A, Arango M, Hartzenberg B, Khamis H, Yutthakasemsunt S, Komolafe E, Olldashi F, Yadav Y, Murillo-Cabezas F, Shakur H, Edwards P (2004) Effect of intravenous corticosteroids on death within 14 days in 10008 adults with clinically significant head injury (MRC CRASH trial): randomised placebo-controlled trial. Lancet 364:1321-1328

Romero IA, Radewicz K, Jubin E, Michel CC, Greenwood J, Couraud PO, Adamson P (2003) Changes in cytoskeletal and tight junctional proteins correlate with decreased permeability induced by dexamethasone in cultured rat brain endothelial cells. Neurosci Lett 344:112-116

Sadowska GB, Malaeb S, Stonestreet BS (2010) Maternal glucocorticoid exposure alters tight junction protein expression in the brain of fetal sheep. Am J Physiol Heart Circ Physiol 298:H179-H188

Saitou M, Fujimoto K, Doi Y, Itoh M, Fujimoto T, Furuse M, Takano H, Noda T, Tsukita S (1998) Occludin-deficient embryonic stem cells can differentiate into polarized epithelial cells bearing tight junctions. J Cell Biol 141:397-408

Saitou M, Furuse M, Sasaki H, Schulzke JD, Fromm M, Takano H, Noda T, Tsukita S (2000) Complex phenotype of mice lacking occludin, a component of tight junction strands. Mol Biol Cell 11:4131-4142

Sakai DD, Helms S, Carlstedt-Duke J, Gustafsson JA, Rottman FM, Yamamoto KR (1988) Hormone-mediated repression: a negative glucocorticoid response element from the bovine prolactin gene. Genes Dev 2:1144-1154

Saul TG, Ducker T, Salcman M, Carro E (1981) Steroids in severe head injury: a prospective randomized clinical trial. J Neurosurg 54:596-600

Schaaf MJM, Cidlowski J (2003) Molecular mechanisms of glucocorticoid action and resistance. J Steroid Biochem Mol Biol 83:37-48

Schneeberger EE, Lynch RD (1992) Structure, function and regulation of cellular tight junctions. Am J Physiol 262:L647-L661

Schweingruber N, Reichardt S, Lühder F, Reichardt HM (2011) Mechanisms of glucocorticoids in the control of neuroinflammation. J Neuroendocrinol 24:174-182

Screpanti I, Morrone S, Meco D, Santoni A, Gulino A, Paolini R, Crisanti A, Mathieson BJ, Frati L (1989) Steroid sensitivity of thymocyte subpopulations during intrathymic differentitation. Effects of 17 beta-estradiol and dexamethasone on subsets expressing T cell antigen receptor or IL-2 receptor. J Immunol 142:3378-3383

Silwedel C, Förster C (2006) Differential susceptibility of cerebral and cerebellar murine brain microvascular endothelial cells to loss of barrier properties in response to inflammatory stimuli. J Neuroimmunol 179:37-45

Singer KL, Stevenson B, Woo PL, Firestone GL (1994) Relationship of serine/threonine phosphorylation/dephosphorylation signaling to glucocorticoid regulation of tight junction permeability and ZO-1 distribution in non-transformed mammary epithelial cells. J Biol Chem 269:16108-16115

Sloka JS, Stefanelli M (2005) The mechanism of action of methylprednisolone in the treatment of multiple sclerosis. Mult Scler 11:425-432

Sospedra M, Martin R (2005) Immunology of multiple sclerosis. Annu Rev Immunol 23:683-747

Steinman L (2001) Multiple sclerosis: a two-stage disease. Nat Immunol 2:762-764

Subramaniam N, Cairns W, Okret S (1998) Glucocorticoids repress transcription from a negative glucocorticoid response element recognized by two homeodomain-containing proteins, $\mathrm{Pbx}$ and Oct-1. J Biol Chem 273:23567-23574

Taddei A, Giampietro C, Conti A, Orsenigo F, Breviario F, Pirazzoli V, Potente M, Daly C, Dimmeler S, Dejana E (2008) Endothelial adherens junctions control tight junctions by VE-cadherinmediated upregulation of claudin-5. Nat Cell Biol 10:923-934

Tischner D, Reichardt H (2007) Glucocorticoids in the control of neuroinflammation. Mol Cell Endocrinol 275:62-70

Tsai MJ, O'Malley BW (1995) Molecular mechanisms of action of steroid/thyroid receptor superfamily members. Annu Rev Biochem 63:451-486

Tsukita S, Furuse M, Itoh M (2001) Multifunctional strands in tight junctions. Nat Rev Mol Cell Biol 2:285-293

Umland SP, Schleimer R, Johnston SL (2002) Review of the molecular and cellular mechanisms of action of glucocorticoids for use in asthma. Pulm Pharmacol Therap 15:35-50

Wallace AD, Cidlowski J (2001) Proteosome-mediated glucocorticoid receptor degradation resticts transcriptional signaling by glucocorticoids. J Biol Chem 276:42714-42721 
Wang D, Müller N, McPherson KG, Reichardt HM (2006) Glucocorticoids engage different signal transduction pathways to induce apoptosis in thymocytes and mature T cells. J Immunol 176:1695-1702

Weidenfeller C, Schrot S, Zozulya A, Galla HJ (2005) Murine brain capillary endothelial cells exhibit improved barrier properties under the influence of hydrocortisone. Brain Res 1053:162-174

Weksler BB, Subileau E, Perriere N, Charneau P, Holloway K, Leveque M, Tricoire-Leignel H, Nicotra A, Bourdoulous S, Turowski P, Male DK, Roux F, Greewnrood J, Romero IA, Couraud PO (2005) Blood brain barrier specific properties of a human adult brain endothelial cell line. FASEB J 19:1872-1874
Wikstrom AC, Okret S, Bakke O, Fuxe K, Gustafsson JA (1986) Glucocorticoid mechanism of action: monoclonal antibodies as experimental tools. Med Oncol Tumor Pharmacother 3:185-196

Wolburg H, Lippoldt A (2002) Tight junctions of the blood brain barrier: development, composition and regulation. Vasc Pharmacol 2002: 323-337

Yang Y, Estrada E, Thompson JF, Liu W, Rosenberg GA (2007) Matrix metalloproteinase-mediated disruption of tight junction proteins in cerebral vessels is reversed by synthetic matrix metalloproteinase inhibitor in focal ischemia in rat. J Cereb Blood Flow Metab 27: 697-709 